\title{
Tracing Metaphor Transformations in Translation of Fiction by Type and Density
}

\author{
Ivaylo Dagnev \\ Medical University - Plovdiv, Medical College, BULGARIA \\ Zlatka Chervenkova \\ Paisii Hilendarski University of Plovdiv, Department of Philology, BULGARIA
}

Received: 20 February 2021 - Accepted: 10 April 2021 - Published Online: 18 April 2021

\begin{abstract}
Heavily neglected by language scholars and ascribed poetics value only, metaphor was reinvented by Lakoff and Johnsons' iconic study in the 1980s, which showed its pervasiveness in language and thought. Paradoxically, though, the Conceptual Metaphor Theory, especially in its early variants, alienated metaphor research from poetics. The latter has slowly been finding its feet in conceptual metaphor studies, especially with the help of newly developed fields of linguistic research such as corpus studies, which allow for obtaining of ample material for cross-cultural analysis. This paper is an example of such an analysis and aims by identifying the conceptual metaphors behind the metaphorical linguistic expressions in key texts from five of the greatest stylists of the English language, and by comparing them to their translations into Bulgarian, to find out whether metaphor is lost or transformed in any way. The main methodological tool used in the current paper is parallel text analysis. Our findings regarding literature in translation, suggest that the target texts (the translated ones) are not inferior in terms of metaphor type and density to the original ones and are appropriate for close reading.
\end{abstract}

Keywords: cross-cultural analysis, Conceptual Metaphor Theory, translation studies.

\section{Introduction}

\subsection{Understanding metaphor}

Understanding metaphor has proven a formidable task for philosophers, psychologists and linguists alike for many centuries. Modern scholars have tried to explain metaphor by putting forward a number of theories based on Aristotle's concept of the term and drawing upon Richards' ideas (Richards, 1981). Basically, there are two distinct views of the metaphor phenomenon. On the one hand, there is the traditional view in which metaphor functions only at the level of language. The second view, pioneered by Lakoff and Johnson (1980), advanced over the last thirty years or so, holds that metaphor is a conceptual device relating to thought and has an elaborate relationship with language. Resting on the latter premise, metaphor studies developed into an important area of research having implication in multiple areas of scientific inquiry associated with language, culture, translation, and literature. Thus, the Conceptual Metaphor Theory, firmly entrenched into the cognitive realm, generated

(C) Authors. Terms and conditions of Creative Commons Attribution 4.0 International (CC BY 4.0) apply. Correspondence: Ivaylo Dagnev, Medical University - Plovdiv, Medical College, BULGARIA. E-mail: ivaylo.dagnev@mu-plovdiv.bg 
I. Dagnev \& Z. Chervenkova - Tracing Metaphor Transformations in Translation of Fiction by...

interdisciplinary research with translation studies (Van Den Broeck, 1981; Dagut, 1987; Mandelblit, 1995; Schäffner, 2004; Dickins, 2005), discourse analysis (Musolff, 2004; CharterisBlack, 2004), education (Cameron, 2003), and more recently, cognitive poetics (Tsur, 1992; Stockwell, 2002).

- Conceptual metaphors were identified in five key texts in English literature.

- Metaphors were compared to their translations into Bulgarian.

- Not many cases of explication, paraphrase and loss of metaphor were found.

- The number of lexicalized metaphors is greater than that of original metaphors.

- Novel metaphors translate readily in the target texts.

\subsection{Translation and Metaphor}

In terms of structure and etymology, both words "translation" and "metaphor" are very close: translation comes from the Latin "transferre", trans - 'across', ferre - 'carry'. Metaphor, similarly, derives from the Greek "meta" - "change" and "pherein" - "carry" (etymonline.com). Both imply source and target domains, languages, cultures. The Bulgarian word превод contains the same connotations. Tymoczko (2007: 68-77) concludes that in most Indo-European languages the words translation, metaphor, and transfer are conceptually related.

What comes as the point of intersection of these notions is the peculiar fact that a central problem of translation is metaphor translation (Newmark 1988). The complex character of metaphor makes its rendition into a target language problematic. Many attempts have been made to study various aspects of metaphor in translation linking the two areas of research (Kloepfer, 1967). Fernandez (2005) provides an exhaustive inventory of the different approaches based on cultural, textual and cognitive characteristics. On the whole, in her view, these standpoints vary from the idea that as metaphoric nature is unpredictable, so its adequate translation is impossible (Vinay \& Darbelnet, 1958; Nida, 1964; Dagut, 1976, 1987). A more moderate stance is held by theoreticians such as Mason (1982) endorsing a degree of translatability while acknowledging its problematic character. Finally, with a view to the full transfer of meaning (Van Den Broeck, 1981; Newmark, 1985, 1988; Toury, 1995), there are positions supported by the abovementioned and also by Translation Studies scholars such as Kloepfer (1967) and Reiss (2000), claiming that metaphors are fully translatable and pose no special problem for translation. In line mostly with the substitution theory of metaphor (Martin \& Harré, 1982: 90), Translation Studies analysts use terms like "image" or "vehicle" for the conventional referent, "object" or "topic" for the actual unconventional referent, and "sense", "ground", or "tenor" for the similarities involved (Schäffner, 2004: 1255). The heated debates circle around the degree of translatability bringing forward the notion of dead, lexicalized and stock metaphors. A "dead" metaphor is a lexical item with a conventional meaning different from its original meaning (Pawelec, 2006). "Lexicalized" metaphors are uses of language which are recognizably metaphorical, but whose meaning in a particular language is relatively clearly fixed (Dickins et al., 2002). A "stock" metaphor can be adapted into a new context by its speaker or writer, e.g., "To carry coal to Newcastle".

Newmark (1988: 106-113), asserts that the only fully translatable metaphors are "dead" ones, as they show the greatest proximity of the two polysystems involved and suggests (Newmark 1981:87-91) a classification based on seven options, focusing on linguistic systems. In his turn, Van Den Broeck's opts for three possible outcomes: translation "sensu stricto", "substitution" and "paraphrase". Both Van Den Broeck (1981) and Alvarez (1993) see lexicalized metaphors as the "most translatable" ones, while considering "novel" metaphors to be extremely difficult to translate and "stock" metaphors fully translatable if the systems involved are culturally 
close (Alvarez, 1993: 137). Snell-Hornby (1988) in her turn focuses on both intralinguistic and extralinguistic factors affecting a translator's process of metaphor rendition. Recently, equivalence also entails "anomalous equivalence" (Toury, 1985: 25) such as "zero solutions" or even creating metaphor where there exists none in the ST.

\subsubsection{Metaphor translation theories in cognitive science}

Cognitive science radically breaks away from the purely linguistic understanding of metaphor. The appearance of the Conceptual Metaphor Theory (CMT), as well as the more discourse and culture-oriented translation theories proposed over the last thirty years, have changed both the view on metaphor and also the importance of the latter for translation studies. There are several models which study the process of metaphor translation from a cognitive perspective. These are Mandelblit's (1995), Schäffner's (2004), Kovecses' (2005), Al-Hassnawi's (2007), Maalej's (2008) and Iranmanesh and Kaurs' (2010).

Mandelblit (1995) came up with the Cognitive Translation Hypothesis, positing that metaphoric expressions take more time and are more difficult to translate if they exploit a different cognitive domain than the target language equivalent expressions. She considers two schemes for the translation of metaphors:

- Similar mapping conditions (SMC will obtain if no conceptual shift occurs between the metaphors of the two languages).

- Different mapping conditions (DMC occurs when a conceptual shift takes place).

If the first option occurs, Mandelblit believes that a translator should simply choose an equivalent target metaphor, but in the second case the translator should render the ST metaphor through choosing a TL simile, or by a paraphrase, a footnote, an explanation or omission (Mandelblit, 1995).

Al-Hassnawi (2007) follows Mandelblit but has added one more scheme to her Cognitive Translation Hypothesis with regard to the outcome:

- Metaphors having similar mapping conditions but lexically implemented differently (metaphors which are only lexically different due to the ethical system in the TL and SL)

Al-Hassnawi (Ibid.) points out that "[the] only plausible justification for this variation in the use of metaphoric expressions is the fact that users of language map the particular conceptual domain of their own world differently".

For Schäffner (2004) conceptual metaphors can be identical in the source text (ST) and target text (TT) at the macro-level. Structural components make entailments explicit. A metaphor is more elaborate in the TT, while ST and TT employ different metaphorical expressions, which can be combined under a more abstract conceptual metaphor. The expression in the TT reflects a different aspect of the conceptual metaphor.

Kovecses (2005: 131-162) addresses the ways conceptual metaphors are expressed linguistically in different languages and by comparing the linguistic expression of a particular conceptual metaphor in two languages, different kinds of patterns emerge:

- Metaphors of similar mapping conditions and similar lexical realization;

- Metaphors of similar mapping conditions but different lexical realization; 
I. Dagnev \& Z. Chervenkova - Tracing Metaphor Transformations in Translation of Fiction by...

- Metaphors of different mapping conditions but similar lexical realization;

- Metaphors of different mapping conditions and different lexical realization.

Maalej's (2008) view on mapping conditions is very similar to Kövecses's. Maalej argues that there is more to translation "than simply pairing or mapping parameters from a SL to a TL" and that metaphor translation is knowledge-based, involving culture-specific repacking or re-expression.

Perhaps the best cognitive answer to the precognitivist division of metaphor typology by is Müller's (2008) approach, whose line of argument refutes the mutually exclusive distinction between "dead" and "live" metaphors. Metaphors, she argues, operate on the level of language use and not on the one of language system. Accordingly, metaphoricity is a dynamic part of a cognitive activation process in an individual person at a given moment in time. Her claims are substantiated by empirical studies of multimodal metaphors that unite language, gestures, pictures, etc. Her argumentation is also strongly reinforced by the Career of Metaphor Theory (Bowdle \& Gentner, 2005), which establishes an evolutionary path based on structure-mapping theory. The career of metaphor hypothesis postulates a shift in mode of mapping from comparison to categorization as metaphors are conventionalized.

\subsection{Metaphor in literary discourse}

Conceptual Metaphor Theory made us reevaluate the role of metaphor in everyday language (Semino \& Steen, 2008), but also introduced a new viewpoint regarding metaphor in literature, as well. There are two approaches to metaphor in literary discourse. In More than Cool Reason Lakoff and Turner (1989) view poetic metaphor as a new reformulation of conceptual metaphors that we use in our daily life. Poets' challenge and reuse creatively everyday metaphor. In other words, cognitive linguists claim that most poetic language is based on conventional, ordinary conceptual metaphors. Creative/original metaphors are nothing more than a creative reformulation of conventional conceptual metaphor

Other scholars, though, consider poetic metaphors superior to metaphor in the other types of discourse, which makes their comparison impossible because of the way metaphors in literary discourse interact with each other and with other aspects of the texts they appear in. For Semino and Steen metaphor in literary discourse is of higher order than metaphor in other types of discourse, as "This focus on individual language use is of course characteristic of literary studies but also raises the more general issue of metaphor's role in individual's idiolects and personal worldviews" (Semino \& Steen, 2008: 239).

\subsection{Parallel text analysis}

Individuals tend to use language differently. Both author and translator are specialists in conveying meaning through language. Indeed, ideally, the meaning in the original and in the translation needs to be identical. Given the professionalism of both, any differences in the conceptualization of metaphor between the two parallel texts are bound to be either culturally or linguistically motivated. In addition, other translation-related transformations, such as generalization and concretization, as well as domestication and foreignization, tend to occur in the process. This further alienates the source text from the target text. Most importantly, metaphors in ST and TT have to fulfill the same functions, expressed by Goatly (1997: 148): "to fill language gaps; create meaning and memorability; express attitude and ideology". Metaphors also 
have aesthetic value, simultaneously functioning as a powerful cohesive device of the literary work, linking themes and ideas within the text and intertextually, between the work and the other texts.

On the other hand, the study of literature at university level invariably involves working with original texts, very often with select excerpts from works of fiction, to which an analysis is made in the form of close reading, more in line with the empirical study of literature, based on Lakoff and Turner (1989), cognitive stylistics (Semino \& Steen, 2008; Tsur, 1992) and cognitive poetics, with its foundational principles of embodiment, prototypicality and naturalness (Stockwell, 2007), than with literary historiography. Thus, parallel texts provide an opportunity for the study of metaphor as manifest in different languages and cultural environments. The content is a constant, though the languages are different, and the metaphors typical of each language, have evolved differently as people have coined similar or different expressions in the attempt to conceptualize and make sense of their particular surroundings. Parallel texts provide an opportunity to study metaphor universality and variation in culture in similar linguistic context and to analyze the different metaphors used in the two languages that are used to convey one and the same message. In Descriptive Translation studies by default the translational problem are reconstructed through target-source comparison.

\section{Method \\ 2.1 Setup of the study}

Our corpus consists of five crucial texts from five highly acclaimed authors writing in English and their translations. They include a passage from Joseph Conrad's multilayered symbolic novel Heart of Darkness, Virginia Woolf's Mrs. Dalloway, Orwell's 1984, Richard Russo's award-winning novel Empire Falls and James Joyce's The Dead and their translations into Bulgarian, which are analyzed by identifying metaphors in both texts, using Steen's MIP VU approach (Steen at al., 2010)

Conclusions are drawn regarding metaphor translatability in literary discourse, paying particular attention to different mapping conditions during translation and the cases in which metaphors have been omitted.

\subsection{Choice of Corpora}

The selected texts belong to the recognized literary canon and hence have been translated by the most prestigious translators in the country, who have a flair and considerable knowledge of language and literature, though were totally unaware of CMT, since, more often than not, it was not even formulated at the time of their translations. Their extensive knowledge of language and literature, and their innate intuition however, helped them in dealing with the most intricate metaphorical nuances. The texts are such as are frequently analyzed in literature classes at the university level, using the methods of close reading. It involved a close reading of the text, identification of literary devices, such as metaphor, which refer to some aspect, or idea, or mega metaphor evident in the work in general.

\subsection{Metaphor typology in the study according to use (transparency, conventionalization, novelty)}

As our aim is to gauge the translatability and quality of translation, we have adopted an analysis involving both precognitivist and conceptual metaphor categories in order to study metaphor transparency, conventionalization and novelty. To that end we have focused closely on three types of metaphor: 
I. Dagnev \& Z. Chervenkova - Tracing Metaphor Transformations in Translation of Fiction by...

- Sleeping metaphors (lexicalized - non-transparent) - are the lexicalized metaphoric linguistic expressions that may be co-activated under certain circumstances in the text. Although such metaphors are also considered conceptual by some scholars (Lakoff \& Johnson, 1980; Lakoff \& Turner, 1989), we have embraced Müller's (2008) approach and Bowdle and Gentner (2005) hypothesis and have regarded sleeping metaphors as showing low activation in terms metaphoricity. So, by analyzing lexicalized metaphors in their own right, we can establish their level of transparency and hence translatability.

- Linguistically expressed conceptual metaphors (entrenched-conventional and activated in the text) are those linguistic expressions in the literary text that are grounded in experience and that provide structural frames for the interpretation of the text. They show a greater level of metaphor activation and are studied separately from the lexicalized one.

- Creative metaphors (novel) - whose metaphorical meaning is induced and relevant only in the specific context.

\section{Results}

Table 1. Types of metaphor in an excerpt from The Dead by James Joyce

\begin{tabular}{|c|c|}
\hline $\begin{array}{c}\text { Source text } \\
\text { James Joyce: The Dead }\end{array}$ & $\begin{array}{c}\text { Target text } \\
\text { James Joyce: The Dead } \\
\text { Translation into Bulgarian }\end{array}$ \\
\hline $\begin{array}{l}\text { forms were near. His soul had approached that } \\
\text { region where dwell the vast hosts of the dead. } \\
\text { He was conscious of, but could not apprehend, } \\
\text { their wayward and flickering existence. } \\
\text { His own identity was fading out into a grey } \\
\text { impalpable world: the solid world itself which } \\
\text { these dead had one time reared and lived in was } \\
\text { dissolving and dwindling. } \\
\text { A few light taps upon the pane made him turn } \\
\text { to the window. It had begun to snow again. He } \\
\text { watched sleepily the flakes, silver and dark, } \\
\text { falling obliquely against the lamplight. The } \\
\text { time had come for him to set out on his } \\
\text { journey westward. Yes, the newspapers were } \\
\text { right: snow was general all over Ireland. It was } \\
\text { falling on every part of the dark central plain, } \\
\text { on the treeless hills, falling softly upon the Bog } \\
\text { of Allen and, farther westward, softly falling } \\
\text { into the dark mutinous Shannon waves. It was } \\
\text { falling, too, upon every part of the lonely } \\
\text { churchyard on the hill where Michael Furey lay } \\
\text { buried. It lay thickly drifted on the crooked } \\
\text { crosses and headstones, on the spears of the } \\
\text { little gate, on the barren thorns. His sogul } \\
\text { swooned slowly as he heard the snow falling } \\
\text { faintly through the universe and faintly falling, } \\
\text { like the descent of their last end, upon all } \\
\text { the living and the dead. }\end{array}$ & $\begin{array}{l}\text { Наблизо имаше и други сенки. Душата му се бе } \\
\text { добрала до тайния мир, населен от сонма на } \\
\text { мъртвите. Съзнаваше, че ги има - загадъчни, } \\
\text { светливи, - но как да ги усети? Собственото му „аз“ } \\
\text { изчезваше в някакъв сив неосезаем свят: } \\
\text { вещественото битие, в което някога тия мъртъвци } \\
\text { бяха расли и живели, се стапяше в разтление. } \\
\text { Туп-туп: по стъклото леко се почука; той, } \\
\text { сепнат, се извърна. Пак беше заваляло. Със сънен } \\
\text { поглед } \odot \text { гледаше снежинките - как сребърни и } \\
\text { тъмни се носят в светлината. Дошъл бе час за път: } \\
\text { на запад, през Ирландия. Да, в пресата го писаха - } \\
\text { страната спи под преспите, навсякъде, безспир, се } \\
\text { сипе сняг. Снегът засипваше заспалите поля в } \\
\text { средата на острова, ситен се стелеше връз } \\
\text { безлесните баири, връз Аленското тресавище*, а } \\
\text { още по на запад се стелеше, сипкав, над тъмните } \\
\text { размирни вълни на сивата Шанън.* Леко се } \\
\text { стелеше над всяка педя пръст от самотното } \\
\text { гробище, където спеше Майкъл Фюри. Снегът } \\
\text { гъсто се стелеше по стърчащите разкривени } \\
\text { кръстове и надгробните камъни, по железните } \\
\text { остриета встрани на строгите гробищни врата, по } \\
\text { черен трън и по изсъхнал сък. Душата му } \\
\text { застиваше в несвяст, заслушана в снега, който } \\
\text { засипваше всичко, разстилаше се над вселената, } \\
\text { със сипкав съсък засипваше живите и мъртвите и } \\
\text { се спускаше като сън - спокоен сетен сън. }\end{array}$ \\
\hline
\end{tabular}


The colors and fonts used to highlight the translated metaphorical expressions have the following significance: lexicalized metaphor in italic, Conceptual metaphor in bold and creative metaphor is underlined. On the right is the TL, where the same classification is made, and the different colors mark those translations that apply different mapping conditions (red), concretization (green), generalization (blue), formulaic language (pink), $\odot$ metaphor (metaphor lost) or + metaphor (metaphor added) $\odot+$.

Table 1 shows the metaphorical linguistic expressions identified in the ST (James Joyce: The Dead - excerpt) using the MIP VU procedure (Steen et al., 2010) and their translations using various techniques - loss, adding, same and different mapping conditions. On the basis of the analysis, we counted the total number of metaphors in the ST and the TT and found the numbers comparable. The linguistic metaphors trigger metaphors on a macro level. The translator weaves through lexicalized, or fossilized metaphor and novel metaphor, compensating loss, when the language will not allow it, with an extra metaphor, where no metaphor is found in the ST (e.g. - "He watched sleepily the flakes" - “Със сънен поглед..."). In the case of lexicalized metaphor, the proximity of the languages may account for the existence of a similar expression in the target language (eg. "the lonely churchyard" - “самотното гробище”). Changing the mapping inevitably creates a different reception in the reader, as proponents of the theory of untranslatability claim (e.g. - "crooked crosses" - “железните остриета", "descent of their last end” - "се спускаше като сън”) The translator, however, adheres to the authentic tone of the target language, its allegiance is to the target language collocations, phraseologisms and mode of expression.

Conceptual metaphors like LIFE IS A JOURNEY and A LIFETIME IS A DAY and UP IS MORE, which lie at the bottom of the sentence from The Dead: "The time had come for him to set out on his journey westward" have a universal appeal, while others, like "It lay thickly drifted on the crooked crosses and headstones, on the spears of the little gate, on the barren thorns" are culturally limited to readers who have experienced the limitations and pain imposed by religious institutions. These constitute metaphors that work on a macro level and may be even missed by the translator. For example, "crooked" in English may have spatial and moral dimensions, whereas the translation in Bulgarian, a country with a much more liberal attitude to religion, suggests only the spatial dimension of crooked, hence the loss of an important metaphor on a macro level.

Table 2. Types of metaphor in an excerpt from Empire Falls by Richard Russo

\begin{tabular}{|c|c|}
\hline $\begin{array}{c}\text { Source text } \\
\text { Richard Russo: Empire Falls }\end{array}$ & $\begin{array}{c}\odot \text { Target text } \\
\text { Richard Russo: Empire Falls } \\
\text { Translated into Bulgarian }\end{array}$ \\
\hline $\begin{array}{l}\text { WHEN THE BULLDOZERS began to clear } \\
\text { the house site, a disturbing discovery was } \\
\text { made. An astonishing amount of trash- } \\
\text { mounds and mounds of it-was discovered } \\
\text { all along the bank, some of it tangled among } \\
\text { tree roots and branches, some of it strewn up } \\
\text { the hillside, all the way to the top. The } \\
\text { sheer volume of the junk was astonishing, } \\
\text { and at first C. B. Whiting concluded that } \\
\text { somebody, or a great many somebodies, had } \\
\text { had the effrontery to use the property as an } \\
\text { unofficial landfill. How many years had this } \\
\text { outrage been going on? It made him mad } \\
\text { enough to shoot somebody until one of the } \\
\text { men he'd hired to clear the land pointed out } \\
\text { that for somebody, or a great many } \\
\text { somebodies, to use Whiting land for a dump, } \\
\text { they would have required an access road, }\end{array}$ & $\begin{array}{l}\text { Когато булдозерите започнаха да разчистват } \\
\text { строителната площадка на къщата, се направи едно } \\
\text { тревожно откритие. Покрай брега се намериха } \\
\text { удивително количество боклуци - цели купища, } \\
\text { някои от тях заплетени в корените на дърветата и } \\
\text { клоните, други пръснати по хълма чак до Ф самия } \\
\text { връх. Удивително беше самото количество на } \\
\text { боклуците и в началото Ч. Б. Ф Уайтинг реши, че } \\
\text { някой, или голям брой неизвестни лица, бяха } \\
\text { проявили нахалството да използват имота като } \\
\text { нерегламентирано сметище. Колко време беше } \\
\text { продължавало това безчинство? } \\
\text { Той така се беше вбесил, че беше готов да застреля } \\
\text { някого, докато един от мъжете, които беше наел да } \\
\text { разчистят терена, не му обърна внимание, че за да } \\
\text { може някой, или голям брой неизвестни лица, да } \\
\text { използват земята на семейство Уайтинг за бунище, на } \\
\text { тях им би бил необходим път за достъп до имота, а }\end{array}$ \\
\hline
\end{tabular}


I. Dagnev \& Z. Chervenkova - Tracing Metaphor Transformations in Translation of Fiction by...

and there wasn't one, or at least there hadn't been until C. B. Whiting himself cut one a month earlier. While it seemed unlikely that so much junk-spent inner tubes, hubcaps, milk cartons, rusty cans, pieces of broken furniture and the like-could wash up on one spot naturally, the result of currents and eddies, there it was, so it must have. There was little alternative but to cart the trash off, which was done the same May the foundation of the house was being poured.

Spring rains, a rising river and a bumper crop of voracious black flies delayed construction, but by late June the low frame of the sprawling hacienda was visible from across the river where $\mathrm{C}$. B. Whiting kept tabs on its progress from his office on the top floor of the Whiting shirt factory. By the Fourth of July the weather had turned dry and hot, killing off the last of the black flies, and the shirtless, sunburned carpenters straddling the hacienda roof beams began to wrinkle their noses and regard one another suspiciously. What in the world was that smell? такъв нямаше и поне не бе имало, преди Ч. Б. Уайтинг сам да бе прекарал такъв път месец по-рано. Макар и да изглеждаше малко вероятно, че такова количество боклуци - спукани вътрешни гуми, тасове, кутии от мляко, ръждясали консерви, счупени мебели и тем подобни, - са могли по естествен път да бъдат изхвърлени на едно място на брега от теченията или водовъртежите, това беше факт и значи е било възможно. Нямаше друг избор, освен боклуците да бъдат извозени и това беше направено още през същия месец май, когато се наляха основите на къщата.

Пролетните дъждове, придошлата река и необичайно големият Ф брой лакоми зли мухи забавиха строежа, но в края на юни ниската конструкция на Ф разпрострялата се нашироко хасиенда се виждаше откъм другия бряг, където Ч. Б. Уайтинг Ф следеше xода на работата от кабинета си на най-горния етаж на семейната фабрика за ризи. Беше преди Четвърти юли времето се засуши, настъпиха жеги, които унищожиха и последните зли мухи, когато дърводелците, свалили ризите си, изгорели на слънцето, +яхнали „попа“ + на покрива на хасиендата, започнаха да бърчат носове и да се поглеждат един друг подозрително. Каква, за Бога, беше тази миризма?

In this text and in the translation a number of conceptual metaphors are brought to the fore, both as conventional metaphors and as original ones that suggest obliquely the way the riches of the empire in general and the family in particular have been accumulated: MONEY IS DIRT, UP IS MORE (DIRT), PERSON IS PLANT, PERSON IS MACHINE, DESTINATION IS PURSOSE,

Loss of metaphor may be seen as detrimental to the text as generalization: "spent inner tubes", translated as "punctured" overlooks the reference to spent lives, spent efforts, spent health (inner tubes).

Table 3. Total number of identified metaphors

\begin{tabular}{|l|l|l|}
\hline \multicolumn{2}{|l|}{ Total Number of identified metaphors } & TT 214 \\
\hline Text & ST 212 & 55 \\
Text 1 Virginia Woolf & 54 & 50 \\
Text 2 James Joyce & 45 & 36 \\
Text 3 R. Russo & 31 & 46 \\
Text 4 Joseph Conrad & 51 & 28 \\
Text 5 George Orwell & 31 & \\
\hline
\end{tabular}

Contrary to many expectations, the study of parallel literary texts shows that metaphors in the TT often exceed the number in the ST. In spite of linguistic and cultural differences and limitations, the number of metaphors in the source and target texts is fairly comparable. In order to get a detailed picture of which group of metaphors yield to translation more than the rest, we have broken down the metaphors into lexicalized, conceptual, and original and counted them in the ST and TT. As expected, resulting from the different evolution of the languages, their different cultural, geographical and historical development, the lexicalized metaphors (Table 4) proved most difficult to translate. Set phrases and collocations, as well as 
function words work differently in the SL and the TL and the translators fit the meaning in the existing linguistic and cultural molds, sacrificing lexicalized metaphors, which, at the time of the translation (70's and 80's) were not perceived as metaphors at all.

Table 4. Number of lexicalized metaphors

\begin{tabular}{|l|l|l|}
\hline Number of identified lexicalized metaphors & TT -66 \\
\hline Text & ST -79 & 8 \\
Text 1 Virginia Woolf & 9 & 16 \\
Text 2 James Joyce & 18 & 12 \\
Text 3 R. Russo & 18 & 17 \\
Text 4 Joseph Conrad & 20 & 13 \\
Text 5 George Orwell & 14 & \\
\hline
\end{tabular}

The linguistic expressions based on conceptual metaphors (Table 5) are deeply embedded in our thought and reveal much about the way we perceive the world. These metaphors have extra force because they hinge on our worldview and are easy to relate to. They translate readily, though some differences in conceptualization do exist.

Table 5. Number of identified conceptual metaphors

\begin{tabular}{|l|l|l|}
\hline Number of identified conceptual metaphors \\
\hline Text & Source Text -111 & Target Text -98 \\
\hline Text 1 Virginia Woolf & 30 & 29 \\
Text 2 James Joyce & 28 & 26 \\
Text 3 R. Russo & 9 & 6 \\
Text 4 Joseph Conrad & 28 & 23 \\
Text 5 George Orwell & 16 & 14 \\
\hline
\end{tabular}

Finally, the traditional original, known in the past as literary metaphors are hard to miss and translators usually go out of their way to render them in the best possible way. This is evident in the results shown in Table 6 - not a single original metaphor has been omitted.

Table 6. Number of original / creative metaphors

\begin{tabular}{|l|l|l|}
\hline Number of original / creative metaphors & Source Text -93 & Target Text -86 \\
\hline & 26 & 25 \\
Text 1 Virginia Woolf & 28 & 25 \\
Text 2 James Joyce & 11 & 7 \\
Text 3 R. Russo & 14 & 15 \\
Text 4 Joseph Conrad & 14 & 14 \\
Text 5 George Orwell &
\end{tabular}

One of the reasons why the TT is longer than the ST is metaphor paraphrase (Table 7). This occurs when the TL does not offer a suitable corresponding metaphorical expression. Another phenomenon observed in the TT is the existence of a metaphorical linguistic expression, where nothing of the sort is found in the ST. This is often the case with unintended lexicalized metaphor.

Table 7. Metaphor to paraphrase in Source Texts and Target Texts

\begin{tabular}{|l|l|l|l|}
\hline Metaphor to Paraphrase o $\odot$ & & o to Metaphor $\odot+$ & \\
\hline Text 1 Virginia Woolf & 2 & Text 1 Virginia Woolf & 3 \\
\hline Text 2 James Joyce & 4 & Text 2 James Joyce & 2 \\
\hline Text 3 R. Russo & 6 & Text 3 R. Russo & 6 \\
\hline Text 4 Joseph Conrad & 8 & Text 4 Joseph Conrad & 2 \\
\hline Text 5 George Orwell & 4 & Text 5 George Orwell & 1 \\
\hline
\end{tabular}


I. Dagnev \& Z. Chervenkova - Tracing Metaphor Transformations in Translation of Fiction by...

Table 8. Summary of the results from all texts

\begin{tabular}{|l|l|l|}
\hline Count & Original & Translation \\
\hline Number of words & 3521 & 3226 \\
\hline Number of characters & 18967 & 19365 \\
\hline Type / token ratio & $1686 / 3521$ & $1853 / 3226$ \\
\hline $\begin{array}{l}\text { Number of identified } \\
\text { metaphors }\end{array}$ & 212 & 214 \\
\hline $\begin{array}{l}\text { Number of lexicalized } \\
\text { metaphors }\end{array}$ & 79 & 66 \\
\hline $\begin{array}{l}\text { Number of conceptual } \\
\text { metaphors }\end{array}$ & 111 & 98 \\
\hline $\begin{array}{l}\text { Number of original } \\
\text { metaphors }\end{array}$ & 93 & 86 \\
\hline
\end{tabular}

Table 9. Results of the study

\begin{tabular}{|l|l|l|}
\hline Category & Translation & Type \\
\hline Different mapping conditions & 82 & $\begin{array}{l}\text { Lexicalized: 34 } \\
\text { Conceptual: 32 } \\
\text { Original: 16 }\end{array}$ \\
\hline Shift of category towards generalization & 4 & $\begin{array}{l}\text { Lexicalized: 4 } \\
\text { Conceptual: o } \\
\text { Original: o }\end{array}$ \\
\hline Shift of category towards concretization & 16 & $\begin{array}{l}\text { Lexicalized: 5 } \\
\text { Conceptual: 5 } \\
\text { Original: 6 }\end{array}$ \\
\hline
\end{tabular}

Having analyzed the relevant characteristics of the parallel texts in terms of length, richness of vocabulary, number of metaphors in ST and TT and their type, we were interested in obtaining information regarding the translation techniques applied to the translation of the three overarching categories of metaphor: lexicalized, conceptual, and original. Table 8 shows the transformations that the metaphors undergo in translation in terms of changing the mapping conditions, generalization and concretization. Of the 82 metaphors with different mapping condition identified in the texts, half of the lexicalized and conceptual metaphors had changed mapping conditions in the translation. This is due to the different conceptualization of the world in the different cultures and its reflection on language. In only a quarter of the original metaphors, however, the mapping conditions were different. These are cases in which the translator, on the basis of his/her personal judgement has changed the mapping. As our results show, this happens less frequently in original metaphors.

The other transformations, generalization and concretization, on the other hand are mostly language motivated, selected by the translator because of existing collocations in the target language. Concretization occurs four times as frequently as generalization because languages differ in the concrete conceptualizations, not the general ones.

\section{Discussion}

Though there are considerable dynamics and transformation of metaphor during translation, at the end of the day, the final counts by category are largely similar. A large number of metaphors in translation have the same mapping conditions in English and Bulgarian, due to common cultural background and globalization. This is in line with other studies, such as the one by Burmakova and Marugina (2014), who investigate metaphor translation in literary discourse, 
Chervenkova (2015), who applies a similar to our analysis but confined to one text, Park (2009), focusing on the analysis of metaphor translation in the short story genre.

Also, terminology, with which one of the texts ("Heart of darkness") abounds in, largely made up of metaphor, is standardized and substituted by common words and phrases in translation, because, as a language of a sea-faring nation, English has more sea-related words than Bulgarian.

In literary discourse, owing to the clustering of metaphors in nodes, in spite of the loss of metaphor, due to linguistic, and culture-related differences, or translator-related preferences, the author's message still gets across in translation, mainly because of the metaphor network that spreads throughout the text, and the possibility of the translator to compensate for the 'zero solutions', or the loss of a metaphor by introducing another metaphor in a place where no such metaphor exists in the original. Similar results are obtained by Swain (2014) in her research into the intertextual perspectives of metaphor translation of literary texts, firmly established on Lemke's semantically-based theory of intertextuality.

Toury's law of growing standardization (1995) is not applicable to the translation of highbrow literature by well-established and experienced literary translators. The study described here reveals that the shifts to concretization are more frequent than the shifts toward generalization.

Lexicalized metaphors suffer more transformations that the other two types because they are more culture-specific and entrenched in language. The creative metaphors suffer the fewest transformations.

Foregrounded metaphors, grammatical metaphors and culturally bound ones turned out to be the ones most difficult to translate.

An interesting study may be the one which could deal with conceptual metaphor typology (e.g., structural, ontological, orientation metaphors) but we consider it the subject matter of a separate paper, as it requires both a thorough theoretical and detailed step-by-step analysis of conceptual metaphors on a heatedly disputed category.

\section{Conclusions}

Judging from the data we can convincingly state that the TT is not longer than the ST and that the type/token ratio is not greater in the TT (Olohan, 2002), and there aren't many cases of explication, paraphrase and loss of metaphor. Furthermore, creative metaphors do not predominate. Even in literary texts the number of lexicalized, sleeping metaphor is greater than the number of original metaphors. Creative metaphors were found to translate readily in the TT. Finally, the general assumption that the TT is inferior to the ST and is not be suitable for close reading and analysis because of metaphor loss, was found to be completely wrong.

\section{Acknowledgements}

This research did not receive any specific grant from funding agencies in the public commercial, or not-for-profit sectors.

The authors declare no competing interests. 
I. Dagnev \& Z. Chervenkova - Tracing Metaphor Transformations in Translation of Fiction by...

\section{References}

Al-Hasnawi, A. R. 2007. A cognitive approach to translating metaphors. Translation Journal, 11(3). Retrieved 22 November 2017, from http://translationjournal.net/journal/41metaphor.htm.

Alvarez, A. (1993). On translating metaphor. Meta, 38(3), 479-490.

Baker, M. (1992). In other words: A coursebook on translation. London and New York: Routledge.

Burmakova, E., \& Marugina, N. (2014). Cognitive approach to metaphor translation in literary discourse. The XXV annual international academic conference, Language and Culture, 20-22 October 2014, Procedia - Social and Behavioral Sciences, 154, 527-533.

Cameron, L. (2003). Metaphor in educational discourse. London. New York: Continuum.

Charteris-Black, J. (2004). Corpus approaches to critical metaphor analysis. Palgrave, Macmillan.

Chervenkova, Z. (2015). Is metaphor lost in translation: A cogno-cultural analysis of metaphor in close readings of literature in translation. Paisii Hilendarski University of Plovdiv - Bulgaria, Research Papers, VOL. 53, Book 1, Part A, 2015 - Languages and Literature.

Dagut, M. (1976). Can metaphor be translated? Babel, 22(1), 21-33.

Dagut, M. (1987). More about the translatability of metaphor. Babel, 33(2), 77-83.

Dickins et al (2002). Thinking Arabic translation. A course in translation method: Arabic to English. Routledge.

Dickins, J. (2005). Two models of metaphor translation. Target, 17(2), 217-273.

Fernadez, E. S. et al., (2005). Translations we live by: the impact of metaphor translations in target systems. Servicio de Publicaciones e Intercambio Editorial de la UVA, edited by Fuertes Olivera, Cood (pp. 61-81). Available from Pedro A. Fuertes-Olivera, Aug 17, 2017.

Goatly, A. (1997). The language of metaphors. London: Routledge.

Iranmanesh, A., \& Kaur, G. S. (2010). A cognitive approach and translation strategies used in the subtitling of metaphors in three American movies. Retrieved 31 January 2017, from http://english.um.edu.my/anuvaada/PAPERS/IRANMANESH AND KAUR.pdf.

Kloepfer, R. (1967). Die Theorie der literarischen Übersetzung. Romanisch-deutscher Sprachbereich. Munich, W. Fink (Freiburger Schriften zur Romanischen Philologie 12).

Kövecses, Z. (2005). Metaphor in culture: Universality and variations. Cambridge: Cambridge University Press, 131-162.

Lakoff, G., \& Johnson, M. (1980). Metaphors we live by. Chicago: University of Chicago Press.

Lakoff, G., \& Turner, M. (1989). Philosophy in the flesh: The embodied mind \& its challenge to Western thought. Basic Books.

Lemke, J. (2009). Intertextuality and the project of text linguistics: A response to de Beaugrande. Text \& Talk, 2O(2), 221-225.

Maalej, Z. (2008). Translating metaphor between unrelated cultures: A cognitive-pragmatic perspective. Sayyab Translation Journal, 1, 60-81.

Mandelblit, N. (1995). The cognitive view of metaphor and its implications for translation theory. In Translation and Meaning, Part 3, 483-495.

Martin, J., \& Harré, R. (1982). Metaphor in science. In D. S. Sussex (Ed.), Metaphor: Problems and perspectives (pp. 89-105). The Harvester Press.

Mason, K. (1982). Metaphor and translation. Babel, 28(3), 140-149. 
Musolff, A. (2004). Metaphor in political discourse. New York, Palgrave Macmillan.

Müller, C. (2008). Metaphors dead and alive, sleeping and waking. Chicago: University of Chicago Press.

Newmark, P. (1981). Approaches to translation. Oxford, Pergamon.

Newmark, P. (1985). The translation of metaphor. In W. Paprotté \& R. Dirven (Eds.), The ubiquity of metaphor (pp. 295-326). Amsterdam \& Philadelphia: John Benjamins Publishing Company.

Newmark, P. (1988). A textbook of translation. Hemel Hempstead, Prentice Hall International.

Nida, E. A. (1964). Towards a science of translating, with special reference to principles and procedures involved in bible translating. Leiden, E. J. Brill.

Olohan, M. (2002). Comparable corpora in translation research: Overview of recent analyses using the translational English corpus. In Yuste, Elia (Ed.) Proceedings of the First International Workshop in Language Resources for Translation Work and Research. Paris, ELRA (European Association for Language Resources).

Park, O. (2009). The issue of metaphor in literary translation: Focusing on the analysis of a short story translation. Journal of Language \& Translation, 155-175.

Pawelec, A. (2006). The death of metaphor. Studia Linguistics. Universitatis Iagellonicae Cracoviensis, $123,117-122$.

Reiss, K. (2000). Translation criticism, the potentials and limitations: Categories and criteria for translation quality assessment. Translated by Erroll F. Rhodes, Manchester, U.K, St. Jerome Pub.

Richards, Iv. (1936). The philosophy of rhetoric. Oxford University Press.

Schäffner, C. (2004). Metaphor and translation: some implications of a cognitive approach. Journal of Pragmatics, 36, 1253-1269.

Semino, E., \& Steen, G. (2008). Metaphor in literature. In R. W. Gibbs, Jr. (Ed.), The Cambridge handbook of metaphor and thought. Cambridge University Press (pp. 232-246). https://doi.org/10.1017/CBO9780511816802.015

Snell-Hornby, M. (1988). Translation studies: An integrated approach. Amsterdam: John Benjamins Publishing Company.

Steen, G., Dorst, L., Herrmann, J. B., \& Pasma, T. (2010). A method for linguistic metaphor identification: From MIP to MIPVU. John Benjamins Publishing.

Stockwell, P. (2002). Cognitive poetics. An introduction. London and New York: Routledge.

Stockwell, P. (2007). Cognitive poetics and literary theory. Journal of Literary Theory, 1/1, 135-152.

Swain, E. (2014). Translating metaphor in literary texts: An intertextual approach. In D. Miller \& E. Monti (Eds.), Tradurre Figure. Translating Figurative Language. Quaderni del CeSLiC Atti di Convegni CeSLiC - 3, Selected Papers.

Tsur, R. (1992) Toward a theory of cognitive poetics (in English). Amsterdam: Elsevier (North Holland) Science Publishers. 580 pp.

Toury, G. (1995). Descriptive translation studies and beyond. Amsterdam \& Philadelphia: John Benjamins Publishing Company.

Tymoczko, M. (2007). Enlarging translation, empowering translators. Manchester, St. Jeromep, 68-77.

Van Den Broeck, R. (1981). The limits of translatability exemplified by metaphor translation. Poetics Today, 2, $73-87$.

Vinay, J. P., \& Darbelnet, J. (1958). Translation procedures. Translated by Andrew Chesterman. In A. Chesterman (Ed.), Readings in translation theory (pp. 61-69). Helsinki, Oy Finn Lectura. 
I. Dagnev \& Z. Chervenkova - Tracing Metaphor Transformations in Translation of Fiction by...

$* * * * *$

Online Etymological Dictionary. https://www.etymonline.com/word/metaphor

Conrad, J. (2008). Heart of darkness. Oxford: Oxford University Press. [Конрад, Дж. (2018). Сърцето на мрака. Хеликон, прев. Григор Павлов.]

Joyce, J. (1914). “The Dead.” Dubliners. London: Penguin, 200o. 175-225. [Джойс, Дж. (2016) „Мъртвите“: Дъблинчани. Изд. Колибри, прев. Асен Христофоров.]

Orwell, G. (1977). Nineteen Eighty-Four. London: Penguin. [Оруел, Дж. (1989). 1984. Профиздат прев. Лидия Божилова - Аройо https://biblioman.chitanka.info/books/11641.]

Russo, R. (2001). Empire falls. New York: Vintage Books. [Русо, Р. (2013) Емпайър фолс. Сиела, прев. Й. Костурков.]

Woolf, V. (2000). Mrs. Dalloway. Oxford: OUP. [Улф, В. (2011) Госпожа Далауей, Колибри, прев. Мариана Неделчева.] 